\title{
THE AETIOLOGY, PREVENTION AND TREATMENT OF SIMPLE GOITRE
}

\author{
A. W. SPENCE, M.A., M.D., F.R.C.P. \\ Physician, St. Bartholomew's Hospital, London, E.C.I
}

\section{Introduction}

Simple goitre has afflicted mankind since the earliest times. It was known to the Chinese about I500 B.c., to the ancient Greeks and to the Romans. Humbolt, in 1824 , observed it among the natives of the Andes and Livingstone among those of Central Africa. Two thousand years ago sea salt was known to be beneficial and burnt sea sponge was a remedy in use from the times of the ancient Greeks to the early part of the 19th century. Unknown to the users, these substances are rich in iodine.

The distribution of simple goitre is world-wide. It occurs in all races, in all climates and at all inhabitable altitudes. It arises sporadically, occasionally in epidemics and in certain areas it is endemic. While most of the endemic districts are mountainous, there are numerous exceptions. Goitre is rare in Iceland, in the main islands of Japan, amongst the Esquimaux and usually along the sea coast, the reason being that in these districts the diet of the inhabitants consists largely of sea food which is rich in iodine. The goitre areas of the world are shown in Fig. I : those readers who require fuller information on the prevalence and geographical distribution of endemic goitre should consult the excellent and exhaustive review of the subject by Kelly and Snedden. ${ }^{14}$ The number of goitrous people in the world is unknown, but the total is not far short of 200 million. ${ }^{14}$ In large areas endemic goitre is associated with cretinism, myxoedema, deaf-mutism, sterility, mental deficiency and physical incapacity and it also predisposes to cancer of the thyroid gland. The disease is thus a major problem of public health, but in those countries enjoying a rising standard of living and possessing an enlightened outlook concerning hygienic living conditions and the prophylactic use of iodized salt the incidence has substantially declined during the past 30 years.

\section{Aetiology}

Simple goitre is a chronic enlargement of the thyroid gland due to a compensatory hypertrophy unassociated with any symptoms of excessiveo secretion and is directly caused by increased 3 . secretion of the anterior pituitary thyrotrophic $\omega_{\sigma}$ hormone, the result of a fall in the blood level of $A$ thyroxine. Deficiency of environmental iodine is. $\vec{v}$ the commonest cause of endemic goitre, but there $\vec{\omega}$ are certain endemic areas where no iodine deficiency can be demonstrated and in these some? other factor must be responsible. Furthermore, $\vec{c}$ environmental iodine deficiency cannot explain the occurrence of sporadic goitre. In fact, aetio-logically, endemic goitre and sporadic goitre ape $\bar{\circ}$ different diseases: endemic goitre is due to 9 . exogenous cause, whereas sporadic goitre is 竎员 most cases the result of an endogenous dis:turbance.

Iodine Deficiency.-Largely through the work of David Marine it is almost generally accepted $\stackrel{\square}{\Phi}$ that the essential cause of simple goitre, with $\overrightarrow{\vec{P}}$ some exceptions to be mentioned below, is failure 3 of the thyroid gland to obtain a supply of iodine? sufficient to enable it to elaborate an adequate amount of its iodine-containing hormone. This thyroid deficiency of iodine may be brought about 3 . by $(a)$ deficient intake, $(b)$ deficient absorption: from the alimentary tract, $(c)$ increased excretion. by the kidneys, $(d)$ the ingestion of a substance which prevents the uptake or the retention of $₹$ iodide by the thyroid gland, and $(e)$ increasedo need of the tissues for thyroid hormone. The factors concerned in the genesis of endemic goitre will first be discussed and sporadic goitre will be dealt with separately.

Because the thyroid hormones, thyroxine and 0 triiodothyronine, contain four and three atoms of ${ }_{\mathbb{E}}^{N}$ iodine respectively, on this fact alone it would beo reasonable to conclude that a deficient intake of iodine would starve the gland of this element and $\frac{\widetilde{\Phi}}{\widetilde{D}}$ inevitably reduce the supply of thyroxine, leading.? to thyroid enlargement through increased secretion 0 of thyrotrophin. Further evidence that iodine deficiency causes endemic goitre is as follows: (I) Iodine surveys have shown that where there is 


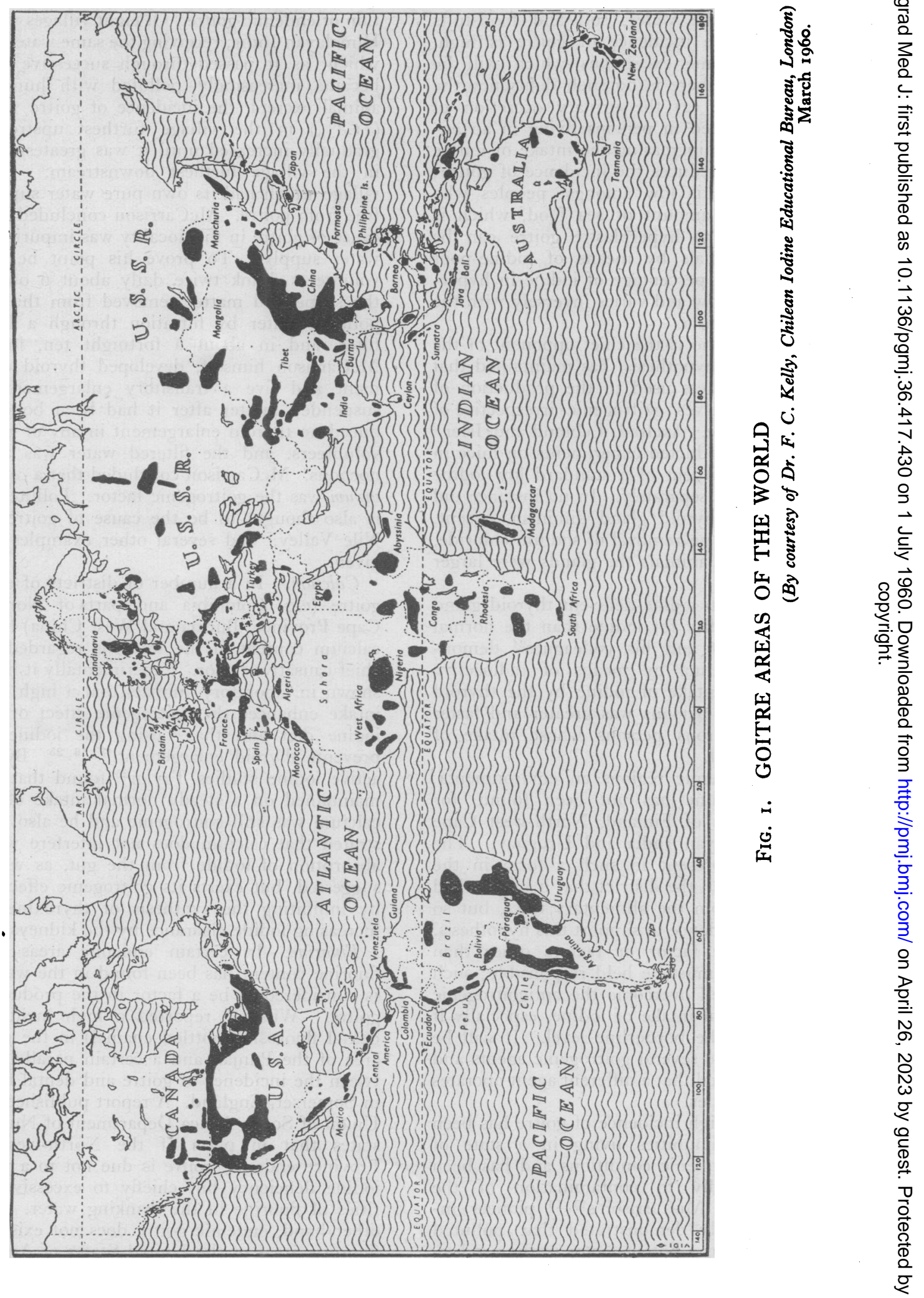


a deficiency in the water, soil and foodstuffs grown therein the incidence of goitre is high, whereas, with some exceptions which will be discussed, where there is no such deficiency the incidence is low; (2) the urinary excretion of iodine is diminished in persons living in an endemic district; (3) increasing the intake of iodine in these districts reduces the incidence of goitre; (4) the incidence is low amongst peoples who consume a large amount of sea food, which is rich in iodine; (5) hyperplastic goitre can be produced in animals by means of iodine-poor diets; and (6) the percentage of iodine in hyperplastic goitres is low and varies inversely with the degree of hyperplasia.

Greenwald, ${ }^{10}$ who is the chief opponent of the iodine deficiency hypothesis, has maintained that the iodine-poor diets used in the production of goitre are themselves goitrogenic irrespective of their lack of iodine. Axelrad, Leblond and Isler, ${ }^{2}$ however, have conducted experiments on mice in which each constituent of a standard low-iodine diet was removed separately. In no instance did the size of the thyroid gland diminish, except, strangely enough, on removal of sodium chloride, but even in these animals the glands were larger than normal.

Furthermore, an iodine-deficient thyroid gland has a greater avidity for iodine than the normal gland. Stanbury and his colleagues ${ }^{24}$ demonstrated in Argentina by means of radioactive iodine that the uptake of iodine by the thyroid gland of goitrous persons was greater and faster than in non-goitrous persons whose intake of iodine was normal.

In certain endemic regions an environmental deficiency of iodine has not been found, for instance, in parts of Finland, North-west Cape Province, Himalayan India and Uruguay. The iodine may be present in such a form in the foodstuffs grown in the district that it is absorbed with difficulty from the alimentary tract, but so far there is no evidence to support this hypothesis. Some goitrogenic factor or factors other than iodine deficiency must be held responsible; such a factor could well overcome the antigoitrogenic action of a normal intake of iodine, especially if the intake is at the borderline level. It will be seen that there are several goitrogenic agents and it has been observed that a different agent operates in different localities.

Pollution.-A high incidence of goitre has been observed in communities living in a state of poverty and unhygienic conditions and has been ascribed repeatedly to contamination of the drinking water. McCarrison's's, 16 pioneer investigations clearly demonstrated that polluted drinking water was a potent factor in the produc- tion of endemic goitre. Of eight villages in Gilgit Himalayan India, receiving the same water supplys which, as it passed through successive villages ${ }_{2}^{\mathbb{D}}$ became increasingly polluted with human and. animal excreta, the incidence of goitre was leas $(11.8 \%)$ in the village furthest upstream and ${ }^{f}$ gradually increased until it was greatest $45.6 \%$ \% in the village furthest downstream. A nintio village which had its own pure water supply was? free from goitre. McCarrison concluded that the cause of goitre in this locality was impurity of the water supply. To prove his point he and 350 volunteers drank twice daily about 6 ounces of the suspended matter removed from the grossly $\vec{\omega}$ polluted water by filtration through a Berkfelgo filter, and in about a fortnight ten, includinge McCarrison himself, developed thyroid enlarge 3 . ment and five a transitory enlargement. The suspended matter after it had been boiled pro- $\rightarrow$ duced no thyroid enlargement in any of $3 \mathrm{I}$ other. volunteers. and the filtered water was also in $\bar{w}$ nocuous. McCarrison concluded that a contagium vivum was the goitrogenic factor. Polluted water is also thought to be the cause of goitre in the Nile Valley, ${ }^{7}$ and several other examples can be given.

Calcium.-In a number of districts of endengic $\vec{\circ}$ goitre (e.g. Colombia and parts of North-we Cape Province, Burma and West China) the high calcium content of the water is regarded as thes chief causative factor. Experimentally it has beeno음 shown in laboratory animals that a high calciumo intake enhances the goitrogenic effect of a low- -0 iodine diet and that raising the iodine intake $\vec{P}$ prevents thyroid enlargement. ${ }^{13,26,25}$ By radio-亏 active iodine studies Taylor ${ }^{25}$ found that in rats? maintained on a steady normal intake of iodideo calcium was still goitrogenic and he also demonstrated that calcium does not interfere with the absorption of iodide from the gut, as was onceo suggested, but exerts its goitrogenic effect eithe? by inhibiting the synthesis of thyroxine or byo increasing iodide clearance by the kidneys.

Fluorine. - In certain endemic areas a high? fluorine content has been found in the water ands is considered to be a factor in the production of goitre. Wilson ${ }^{29}$ reported a high incidence of dental fluorosis (mottled enamel) in the goitrous area of the Punjab and a certain parallelism be 0 tween the incidence of goitre and dental fluorosis in Somerset, England. A report published by the Union of South Africa Department of Nutrition ${ }^{2} \mathrm{E}$ states that in parts of the North-west Cape Province endemic goitre is due not to a primary? iodine deficiency but chiefly to excessive quan-0 tities of fluorine in the drinking water. On the other hand, endemic goitre does not exist in the fluorosis areas of the United States of America; ;20D 
and in Iceland, where fluorosis is present but endemic goitre absent, the consumption of sea fish is very high. ${ }^{23}$

Foods.-Both McCarrison ${ }^{17}$ and Marine ${ }^{19}$ considered that unbalanced diets were important contributory causes of goitre. Thyroid hyperplasia may be produced in laboratory animals by a high intake of fat or of meat protein and by vitamin deficiency, but on the whole the experimental work on the goitrogenic effect of vitamin deficiency is contradictory and controversial. In the Chin country of Burma dietary deficiency of vitamin $A$ is notorious and is considered to be the most important single goitrogenic factor, while in parts of Sierra Leone the seasonal scarcity of vitamin A may possibly help to precipitate goitre when the iodine content of the diet is borderline. ${ }^{14}$

The discovery of the goitrogenic action of cabbage in rabbits ${ }^{5}$ aroused world-wide interest and it was later found that a similar effect on the thyroid gland was produced by other members of the genus Brassica, namely, brussels sprouts, cauliflower, kohlrabi, rape, rutabaga (swede), savory and turnip. The seeds of all the Brassicae also possess goitrogenic activity. Greer and Astwood, 11 however, using the radioactive iodine uptake by the thyroid gland as an indicator, were unable to demonstrate that cabbage had any antithyroid activity in man, although rutabaga and turnip had. Investigators have endeavoured to determine the active principle in these goitrogenic plants and seeds and suspicion has centred on the mustard oils, organic cyanides, thiocyanate and the thioureas, but so far only one goitrogenic substance has been isolated, vinyl-thio-oxazolidone. Greer, Ettlinger and Astwood ${ }^{12}$ obtained this compound from the seeds of rutabaga, turnip, cabbage, kale and rape and also synthesized it. They were unable to detect the substance in the edible portions of any of the Brassicae, except rutabaga and white turnip. In action it is similar to thiouracil and in man it is slightly more active than propylthiouracil. The administration of iodine prevents completely the development of ' cabbage goitre,' but only partially prevents the development of Brassica-seed goitre. (A good review of the relationship of food to the genesis of goitre is that of Fertman and Curtis. ${ }^{8}$ )

In applying these findings to the problem of endemic goitre we find that in certain endemic areas (Ruthenia and parts of Morocco and West China) cabbage or turnip is the staple diet, and in Tasmania and New Zealand a kale goitrogen may be present in the milk. ${ }^{6}$ It is of interest that the ' milk goitre' in Tasmania was not prevented by the administration of potassium iodide. The incidence of goitre in Holland and Belgium increased during World War II when the diet con- sisted largely of cabbage, turnip and similar food Antigoitrogenic Substances.-Before discussion of the aetiology of endemic goitre is concluded reference should be made to the possible existence in foodstuffs of substances other than iodine which may neutralize the effects of an existing goitrogen and a deficiency of which may play part in the production of endemic goitre. Maring and his colleagues ${ }^{20}$ showed that the developmen $\frac{}{\Phi}$ of cabbage goitre could be prevented by the feeds 5 . ing of certain fresh plants and that the antigo tro $\mathbb{\Omega}$ genic action of these plants was not likely to b甲 due to iodine.

Sporadic Goitre.-As mentioned above, the

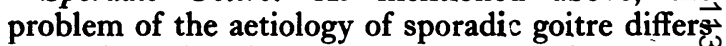
from that of endemic goitre, for a deficiency of environmental iodine or an excess of calcium of fluorine cannot be held responsible. That it development is commonest at the sex periods of a woman's life suggests an endogenous disturbanc $\$$ in some way connected with an interrelationship $\vec{p}$ between the thyroid gland and the ovaries, but the nature of this relationship is uncertain as the results of the experimental work are contra dictory. This endogenous factor may operate to some extent in endemic goitre, for in many endemic regions not all the inhabi'ants have visible or palpable thyroid enlargement.

A few cases of sporadic goitre may be cause by an unbalanced diet as in two patients of Giv J. H. Means who developed goitres when theis diet consisted of large amounts of cabbage; the glands became smaller when the cabbage way omitted and larger when it was resumed. further cause may be excessive loss of iodine in the urine. Cassano and his colleagues ${ }^{4}$ describe eight women with large non-toxic goitres in whom thyroid function appeared to be normal, in whon there was no evidence of deficient intake of iodine or of the consumption of any goitrogenic sub3 stance and whose renal radioactive iodine clearancewas increased, showing that the kidneys were removing iodide from the blood in excessive amounts. The authors suggested that this in creased urinary excretion of iodide might have been the cause of the goitres.

The exceptions to the dictum that the essentia cause of simple goitre is failure of the gland tô obtain enough iodine are (I) those cases of sporadic goitrous cretinism in which the goitre is due to lack of one of the enzymes concerned int the synthesis of thyroxine, and (2) goitre produced by antithyroid substances such as thiouracil and vinyl-thio-oxazolidone which inhibit the synthesie of thyroxine by blocking iodination of tyrosine.

Prevention
Marine $^{18}$ has said, 'Simple goitre is the easies 
and cheapest of all known diseases to prevent and its control may be accomplished by available methods as soon as organized society determines to make the effort.' This can be done by the use of iodized salt in the concentration of one part of potassium iodide to 100,000 parts of salt, as recommended for Great Britain by the Goitre Sub-committee of the Medical Research Council ${ }^{9}$ and by Murray and her colleagues. ${ }^{22}$ With an average daily intake of $10 \mathrm{~g}$. of salt per person this would provide 76 micrograms of iodine per day over and above the usual intake and in this dosage would provoke no ill-effects. One instance, of many, of the beneficial results of iodized salt is in Avenches, Switzerland, where the incidence of goitre in school children in 1921 was $78.9 \%$, iodized salt was introduced in 1924 and in 1951 the incidence was $7.1 \%{ }^{21}$ Improvement in general hygiene and in the water supplies and the provision of a good mixed dietary, which should include an adequacy of sea fish because of its high iodine content, are also factors which would contribute to the elimination of goitre.

\section{Treatment}

Diffuse Non-toxic Goitre.-Diffuse goitre should be treated by the administration of Tab. Laevothyroxine, starting with $0.1 \mathrm{mg}$. daily and increasing to tolerance, the ultimate dose being 0.3 to $0.5 \mathrm{mg}$. daily. This by raising the thyroxine content of the blood suppresses the secretion of thyrotrophin. For the maximal effect a year's treatment may be necessary, but if there is no sign of reduction during the first few months there is no point in continuing. If medical treatment fails the only reasons for removing a diffuse goitre are cosmetic and the development of pressure symptoms. Partial thyroidectomy is contraindicated for puberty goitre and for goitre arising during pregnancy, because both types may diminish in size spontaneously in due course. Partial thyroidectomy may be necessary during pregnancy on account of pressure symptoms, which could arise if the patient had a goitre before pregnancy; two or three drops of Lugol's solution should then be given daily to prevent goitre in the foetus.

Substernal Goitre.--Surgery is always indicated for substernal goitre in case subsequent enlargement either through its growth or haemorrhage into its substarce causes serious pressure symptoms. It is of advantage to treat the condition with thyroxine for a month or two before the operation in an endeavour to reduce its size and so facilitate surgical procedures.

Nodular Non-toxic Goitre.-It is unusual for nodular goitres to respond satisfactorily to medical treatment and long-standing nodular goitres never do. Large nodular goitres are removed for cosmetic reasons, to relieve pressure effects and, according to some authors, in case thyrotoxicosis subsequently arises. The question is: Should a single nodule in a gland or a small multinodular goitre be removed? The answer depends on whether it is considered that the single nodule is malignant and that a multinodular goitre predisposes to malignancy. In the first place it is often impossible to say whether a single nodule is malignant. Increased uptake of radioactive iodine by the nodule provides strong evidence that it is innocent, since a malignant nodule does not trap iodine so well as normal thyroid tissue. Decrease or absence of uptake may or may not indicate malignancy. It seems reasonable to consider that if a single nodule has been present for some years, especially in a person past middle age, and is not increasing in size, it need not be removed. However, thyroidectomy should te performed if the patient states that during the previous months it has become larger and if the nodule is of recent origin. A nursing sister, aged 24 , recently presented with a nodule of recent origin and on its removal it was found to be malignant.

It seems that it is controversial whether nodular goitre predisposes to malignancy. ${ }^{1}$ Lack of space forbids discussion of this subject here: suffice it to state that, according to Bérard and Dunet, ${ }^{3}$ in $75-85 \%$ of cases of thyroid malignancy the condition develops in an old-standing simple goitre and, according to Wegelin, ${ }^{28}$ where goitre is endemic malignant tumours of the thyroid occur in greater numbers. In the author's opinion thyroidectomy should be performed in cases of multinodular goitre.

\section{REFERENCES}

I. Annotation (1959), Lancet, ii, 393.

2. AXELRAD, A. A., LEBLOND, C. P., and ISLER, H. (1955), Endocrinology, 56, 387 .

3. BERARD and DUNET (1924), 'Le cancer thyroidien,' Paris.

4. CASSANO, C., BASHIERI, L., and ANDREANI, D. (1957), Rass. Fisiopat. clin. ter., 29, 253.

5. CHESNEY, A. M., CLAWSON, T. A., and WEBSTER, B. (1928), Bull. Johns Hopk. Hosp., 43, 261.

6. CLEMENTS, F. W., and WISHART, J. W. (1956), Metabolism, 5, 623 .

7. DOLBEY, R. V., and OMAR, M. (1924), Lancet, ii, 549.

8. FERTMAN, M. B., and CURTIS, G. M. (1951), f. clin. Endocr., 11, 1361.

9. Goitre Subcommittee, Medical Research Council (1944), Lancet, $i$, 107.

10. GREENWALD, I. (1946), F. clin. Endocr., 6, 708.

11. GREER, M. A., and ASTWOOD, E. B. (19+8), Endocrinology, 43, 105 .

12. GREER, M. A. ETTLINGER, M. G., and ASTWOOD E. B. (1949), F. clin. Endocr., 9, ro69.

13. HELlWIG, C. A. (1931), Arch. Path., 11, 709.

14. KELLY, F. C., and SNEDDEN, W. W. (1958), Bull. Wld Hlth Org., 18, 5.

15. MCCARRISON, R. (1906), Lancet, i, i 110

16. MCCARRISON, R. (1908), Ibid., ii, 1275.

Continued on page 467 
instances ${ }^{131} \mathrm{I}$ therapy has been followed by an exacerbation of exophthalmos and ophthalmoplegia.

\section{Summạry}

We now have available in ${ }^{131}$ I an agent which is almost universally available, which is free of proven risk, which can be effective in all cases of thyrotoxicosis, and which can achieve results in many patients which would not be feasible with any other form of treatment. Its role in the treatment of thyroid cancer is very limited, but it may become the dominant therapeutic aid for the control of one of the commonest endocrine disorders, thyrotoxicosis.

\section{REFERENCES}

I. BLOMFIELD, G. W., JONES, J. C., MACGREGOR, A. G., MILLER, H., and WAYNE, E. J. (I951), Brit. med. Э.,' ii, 373 .
2. BLOMFIELD, G. W., JONES, J. C., MACGREGOR, A. G., MILLER, H., WAYNE, E. J., and WEETCH, R.S. (1955), Ibid., il, 1223 .

3. BLOMFIELD, G. W., ECKERT, H., FISHER, M., MILLER, H., MUNRO, D. S., and WILSON, G. M. (1959), Ibid., i, 63 .

4. CROOKS, J., BUCHANAN, W. W., WAYNE, E. J., and MACDONALD, E. (1960), Ibid., i, 151 .

5. FRASER, R., ABBATT, J. D., and STEWART, F. S. (1954), Brit. F. Radiol., 27, 23.

6. GREENE, R. (1960), Postgrad. med. F., 36, 468.

7. LARRSON, L. G. (1955), Acta radiol. (Stockh.), Supp. 126.

8. MACGREGOR, A. G. (1957), Brit. med. F., i, 492.

9. MACGREGOR, A. G. (1960), 'Memoirs of Society of Endocrinology,' No. 9 (in press).

10. MYANT, N. B. (1956), "Therapeutic Use of Artificial Radioisotopes,' p. 148. New York: John Wiley.

1 I. MYANT, N. B., and POCHIN, E. E. (1955), 'British Practice in Radiotherapy,' p. 382. London: Butterworth.

12. OSBORN, S. B., and SMITH, E. E. (1956), Lancet, i, 949.

13. POCHIN, E. E. (1958), 'Modern Trends in Endocrinology,' p. 46. London: Butterworth.

14. RIDDELL, V. (1960), Postgrad. med. F., 36, 447.

15. WAYNE, E. J., MACGREGOR, A. G., and BLOMFIELD, G. W. (1952), Brit. med. Bull., 8, 148.

16. WERNER, S. C. (1955), 'The Thyroid.' New York: Harper.

\section{NEWCASTLE SYMPOSIUM}

(Postgraduate Medical Journal, April 1960)

Price 6s. 6d. post free

THE THROMBOGENIC HYPOTHESIS AND

ITS IMPLICATIONS

J. B.-Duguid, M.D.

THE MANAGEMENT OF ACUTE RENAL FAILURE

Walter Elliott, M.B., B.S., Molly Hill, M.B., Ch.B., M.R.C.P., D.R.C.O.G., David N. S, Kerr, M.Sc., M.R.C.P., M.R.C.P.(Edin.), and Rosalind Ashcroft, Ph.D.

CURRENT RESEARCH IN MULTIPLE SCLEROSIS

E. J. Field, M.D., M.S., Ph.D., and Henry Miller, M.D., F.R.C.P.

THE SURGICAL TREATMENT OF PARKINSON'S DISEASE

John Hankinson, M.B.(Lond.), F.R.C.S.

CHRONIC OTITIS MEDIA

F. McGuckin, M.D., F.R.C.S.
SOME RECENT TRENDS AND DEVELOPMENTS IN DERMATOLOGY

G. Holti, M.D., and John T. Ingram, M.D., F.R.C.P.

SOCIAL AND ENVIRONMIENTAL FACTORS IN CHRONIC BRONCHITIS IN NEWCASTLE UPON TYNE

A. G. Ogilvie, M.D., F.R.C.P.

ENQUIRIES INTO MENTAL DISORDER IN OLD AGE

Martin Roth, M.D., F.R.C.P., and D. W. K. Kay, M.A., B.M., D.P.M.

STUDIES OF LUNG FUNCTION IN

\section{CHILDREN}

L. B. Strang, M.B., M.R.C.P., and S. D. M. Court, M.D., F.R.C.P., D.C.H.

EMBOLECTOMY IN THE LIMB ARTERIES

David J. Tibbs, M.C., M.S.(Lond.), F.R.C.S.

Published by

THE FELLOWSHIP OF POSTGRADUATE MEDICINE

60, Portland Place, London, W.1

References continued from page $435-$ A. W. Spence, M.A., M.D., F.R.C.P.

17. MCCARRISON, R., and MADHAVA, K. B. (1932). 'The Life Line of the Thyroid Gland,' p. 347. Calcutta: Thacker, Spink \& Co.

18. MARINE, D. (1924), Medicine, $3,453$.

18. MARINE, D. (1935), Ұ. Amer. med. Ass., ro4, 2334.

20. MARINE, D., BAUMANN, E. J., WEBSTER, B., and CIPRA, A. (1933), ₹. exp. Med., 57, 121.

21. MESSERLI. F. M. (1952), Gesundh. u. Wohlf., 32, $56 \mathrm{r}$.

21. MURRAY M. M. RYLE, I. SIMPSON , 3. W. and WILSON, D. C.' (I948), Med. Res. Coun. Mem. No. 18. London: H.M.S.O.

23. SIGURJONSSON, J. (1940). ' Studies on the Human Thyroid in Iceland.' Reykjavik: Edda.
24. STANBURY, J. B., BROWNELL, G. L., RIGGS, D. S.,

PERINETTI, H.,' ITOIZ, J., and DEL CASTILLO, E. B.

(r954), 'Endemic Goitre.' Harvard University Monograph

in Medicine and Public Health, No. 12 . Cambridge, Mass.

25. TAYLOR, S. (1954), f. clin. Endocr., 14, 1412.

26. THOMPSON, J. (1933), Arch. Path., 16, 211.

27. Union of South Africa Department of Nutrition (1955),

Endemic Goitre in the Union of South Africa and Some

Neighbouring Territories.'

28. WEGELIN, C. (1928), Cancer Rev., 3, 297.

29. WILSON, D. C. (1941), Lancet, i, 21 I. 